\title{
Geography in the Normal Schools of the United States
}

\section{Charles Redway Dryer}

To cite this article: Charles Redway Dryer (1905) Geography in the Normal Schools of the United States, Journal of Geography, 4:5-6, 239-243, DOI: 10.1080/00221340508986035

To link to this article: http://dx.doi.org/10.1080/00221340508986035

曲 Published online: 20 May 2008.

Submit your article to this journal $\widetilde{ }$

Џ Article views: 4

Q View related articles $\longleftarrow$ 


\section{GEOGRAPHY IN THE NORMAL SCHOOLS OF THE UNITED STATES*}

BY CHARLES REDWAY DRYER

Terre Haute, lind.

FUNCTION OF NORMAL SCHOOLS

$7 \mathrm{HE}$ public school system of the United States includes about 145 State Normal Schools, whose function, as generally defined in the act of establishment, is the preparation of teachers for teaching in the common schools of the state. By "common schools" are meant those in which the primary and grammar grades, comprising the first eight years of the school course, are taught. "The "common branches," or those which are universally taught in the common schools, are reading, writing, arithmetic, grammar and geography. To these some states add human physiology, history, English literature, music, drawing, nature study and more rarely, algebra and Latin. The fundamental work of the Normal School is to give instruction in the common branches and in "professional" studies, comprising pedagogy and its various cognate subjects. Most Normal Schools also provide courses of study in some of the secondary, academic, or collegiate branches of learning, which may prepare students to teach in the public high schools.

\section{STANDARDS OF ADMISSION}

The nominal standard of admission to the Normal Schools is the completion of the eighth grade of the public schools, or the possession of a teacher's license obtained by the regular county examination. A few Normal Schools require a diploma from a public high school for admission, but usually special courses of study are provided for such students.

\section{COURSE OF STUDY AND PERIOD OF ATTENDANCE}

The Normal course of study required for graduation varies from one to five years, according to the rank of the student at the time of admission. For the majority of students the length of the course is four years. Probably, on the average, not more than one-third of the students admitted remain until graduation and something like one-half attend the Normal School only one year or less. The majority enter for the purpose of preparing themselves to obtain, for a limited period, higher grades of license and fair positions in the common schools, with no intention of teaching as a

* Read before Educational Section, Eighth International Geographic Congress, Sept., I 904. 
permanent occupation. Consequently the freshman or first year class is apt to be very large, and the ranks of the upper classes to diminish sometimes to one-fifth the number of freshmen.

\section{POSITION OF GEOGRAPHY IN THE NORMAL SCHOOL COURSE}

Geography, being one of the common branches and required for all grades of license to teach, falls, with few exceptions, in the first year of the course, and is taught to students who have had the least preparation. From the pedagogical or scholastic point of view, geography may be differentiated into two well marked varieties: (I) introductory geography, which gives in broad outline a general view of the world and its physical, biological and human activities, and serves as an open door to all the natural, historical and economic sciences; and (2) advanced geography, which comprises a synthesis and correlation of natural science, history and economics. It is evident that under the conditions which prevail in the Normal Schools, all but a small fraction of the geographic work done must be of the introductory variety.

\section{LACK OF PREPARATION ON THE PART OF STUDENTS}

For the Normal School teacher of geography a serious problem arises from the imperfection or absence of preparation on the part of the students. The state courses of study for the common schools include no more than four years of geography, which the child pursues between the ages of nine or ten and thirteen or fourteen. In many cases, by the downward intrusion from the high school of algebra, Latin or German, this has been reduced to three or even two years, and the child "finishes" geography at the age of twelve, when he is just beginning to be able to think. Ten or twenty per cent. of the high schools give a half year or a year to physical geography, but it is often very poorly taught by any teacher who happens to have a vacant period upon his programme. The high school course is usually a convenient period in which to forget the little geography learned in the grades. The result is that the knowledge of geography possessed by the average Normal freshman is difficult to evaluate. It may consist of a mixture in various proportions of blank ignorance, disjointed facts, parrot phrases, and less desirable pieces of pure mythology which stand in the place of scientific explanation. A most lamentable fact is that the geographic knowledge of the student lies so remote from his experience. He has wrestled with such problems as the change of seasons, the cause of tides, and rotational deflection at an age when it was impossible for him to understand them, and has never observed the path of Ursa Major or the varying points of sunrise and sunset. $\mathrm{He}$ is 
apt to know something about Thibet, Abyssinia and the Amazon, and nothing about the hills, valleys and streams of his own neighborhood.

The school geography of forty years ago consisted largely of memoriter recitation of names and locations. This was often so thoroughly done that the child retained through life a very practical knowledge of general descriptive geography. If it were well done to-day, it would furnish a foundation for teaching scientific geography in the high and Normal schools. Memoriter learning has been largely abolished from the grade schools, but scientific learning has hardly begun to come in. The house is empty, swept and garnished and its last state is worse than the first.

\section{PROBLEMS OF NORMAL SCHOOL GEOGRAPHY}

The Normal School is called upon to undertake such large propositions in geography as the following:

(1) It ought to teach the student to read and use the technical language of geography as it is embodied in maps, and this ought to include the higher forms of that language, such as colored, nachured and contoured topographic maps, population, product and weather maps.

(2) It ought to teach a large part of the subject matter of geography. It is never safe to assume that the student possesses any particular portion of it. The subject matter ought to be so taught that the student may realize his concepts and build up in imagination true and adequate models of the features and phenomena of the globe.

(3) It ought to give the student some insight into the methods of scientific investigation and lead him to appreciate the meaning of natural or scientific causation.

(4) It ought to make clear the scope and organization of the science of geography and its relations to other sciences and subjects of study and to practical affairs.

(5) It ought to ground the student in rational methods of teaching geography to common school pupils.

In view of the magnitude of these tasks, perhaps criticism of the results of geographic teaching in Normal Schools ought to be more considerate.

\section{STATISTICS OF NORMAL SCHOOLS}

An attempt has been made to ascertain what the Normal Schools are actually doing in discharge of the heavy geographic responsibilities laid upon them, but with only partial success. An elaborate printed questionnaire addressed to more than one hundred Normal Schools brought but twentyeight replies. The causes of this meager response may be left to conjecture. Partial information was obtained from the catalogues of thirty-two addi- 
tional schools. These sixty schools contain about one-half of all State Normal School students. They generally comprise the larger and presumably more flourishing schools in each state represented, and statistics compiled from them may give a somewhat flattering picture of Normal School geography in the United States.

\section{THE COURSE OF STUDY IN GEOGRAPHY}

The length of the course of study in geography has been computed on the basis of 180 to 200 exercises or periods per year. Of the sixty schools three devote one-fourth to one-third of a year to geography, fifteen one-half year, thirty one year, four one and one-half years, six two years, and two more than two years. The average course is a trifle more than one year.

In the attempt to determine the amount of emphasis laid upon the various phases of geography, the courses of study were classified as follows:

(I) Physiography, including an occasional term or semester of geology.

(2) Commercial geography.

(3) Pedagogical geography.

(4) General geography, comprising cases where no differentiation could be made out. Of fifty schools giving courses in physiography, fifteen devote to it one-third of a year, fourteen one-half year, thirteen two-thirds of a year, seven one year, and one more than one year.

Of thirty-eight schools giving courses in general geography, four devote to it one-fourth of a year, twelve one-third of a year, eight one-half year, five two-thirds of a year, five one year, three one and one-third years, and one two years.

Of sixteen schools giving courses in pedagogical geography, nine devote to it one-eighth to one-third of a year, four one-half year, and three twothirds of a year.

Of nine schools giving courses in commercial geography, six devote to it one-third of a year, two one-half year, and one two-thirds of a year.

A summation of the aggregates of each phase gives to physiography twenty-nine years, to general geography twenty-three and one-third years, to pedagogical geography six years, and to commercial geograply three and two-thirds years. The combinations of these phases in different schools are too various to be classified.

\section{EQUIPMENT}

The quality of the work done in Normal School courses can only be inferred from the equipment, preparation of the teacher and other indirect indications. Of twenty-eight schools reporting, five seem to have a fair equipment of maps, globes, pictures, models, lantern slides and specimens, 
nineteen a good equipment, and four an excellent equipment. Ten have a geographical library of 100 volumes or less, fifteen have from 100 to 500 volumes, and three have more than 500 volumes.

Very few schools possess a specially fitted geographical laboratory, but this is not essential to good work which can be done in the class room or physical laboratory. Twenty-eight schools report some systematic laboratory work, of which twenty-three seem to give a fairly adequate course. Twenty-nine schools report regular field work, consisting of from three to six excursions for each class.

\section{PREPARATION AND DUTIES OF TEACHERS}

In forty-three schools one or more of the instructors in geography have had special university training. While in forty-seven schools the teachers of geography give instruction in other subjects, in twenty-eight of these geography is allied with some other natural science, usually physics or geology, in five with history, and in fourteen with some less cognate subject.

\section{CONCLUSION}

Fifteen years ago geography had hardly been thought of as a natural science and a geographical laboratory scarcely existed in dreamland. No special preparation was thought necessary for the teaching of geography, which was commonly turned over to the teacher of history, or to someone whose chief interests were more remote from the subject. The work consisted largely of a study of political divisions with some map drawing. There was seldom a suggestion that the vicinity of the school might contain geographical features worthy of attention. To one conversant with these facts, the present status of geography in Normal Schools is encouraging. A professional school can hardly be expected to take the lead in promoting a branch of common education elsewhere neglected. As long as only three or four universities in the United States offer substantial courses in geography, teachers with university training in that subject will not be plentiful. In the common and high schools the supply of geography teachers who are as well trained as those in mathematics, languages or history, will await the demand.

While the teaching of geography in the Normal Schools is far from adequate, it is entering upon a new phase in which trained teachers and scientific methods will prevail. Progress is being made and there does not seem to be any occasion for the common schools, high schools or universities to throw stones at the Normal Schools upon this score. There is a fair prospect that the demand and supply of competent teachers of geography, both hitherto very small, may increase at a reasonable rate. 